\title{
KULTUROZNAWSTWO
}

Olga Anchimiuk

Biatystok

\section{Топос явления Святой Троицы святому Александру Свирскому \\ в Житии и Акафисте}

Ключевые слова: топос, житие, акафист

Одним из многочисленных русских святых, который был канонизирован всего через 14 лет после смерти, является святой Александр Свирский ${ }^{1}$. Это единственный известный новозаветный святой, видевший Бога в Трех Лицах. Описанию этого чуда в ЖКитии святого и в Акафисте святому посвящена данная статья.

Почитание святых стало неотъемлемой частью православной духовности. Основаниями для церковной канонизации, то есть причислению к лику святых были и остаются: 1) жизнь и подвиг святого, 2) чудеса и 3) в некоторых случаях нетление его мощей [Федотов 1931, введение].

Напомним, что чудом считается: «доступное вн'шнему наблюденію дњйствие или событіе сверхъестественное, но ни противоестественное, производимое непосредственно силою Божіею для достижения важныхъ религиозныхъ целей на пути спасенія» [ППБЭС].

Исследующий чудо в Католицизме и Православии Йоахим Бюфле рассматривает следующие явления: Схождение Благодатного Огня; Ланчанское чудо (VIII в); Крест в небе Минье; нетленные мощи; чу-

1 Александр Свирский (в миру Амос, 1448-30 августа 1533) - это русский православный святой, почитаемый в лике преподобного. Его мощи полностью нетленны. Всего через 14 лет после смерти Макарьевские собор 1547 года установил его общецерковное почитание. 
до евхаристии; мироточение (источение какого-либо вещества из святыни); кровоточение из святыни. Кроме того, свидетели описывают явления (Иисуса Христа, Божьей Матери, Святых). Явлениям могут сопутствовать свет, приятный запах [Bouflet 2011].

Чудеса обычно сопровождаются исцелениями, в результате чуда происходит изменение мировоззрения, укрепление в вере. Именно чудо-явление святому Александру Свирскому, которому как и ветхозаветному Аврааму явилась Святая Троица, будет рассмотрено в этой статье.

«Когда речь заходит о русских православных святых, следует учитывать, что их христианский подвиг был запечатлен не только в прозаических жизнеописаниях (агиобиографиях, других агиографических жанрах), но и в церковной поэзии (в паралитургических субжанрах канона русским святым и акафиста русским святым), а также - в преломленном виде - и в устном фольклорном творчестве (например, в духовных стихах)» [Давыдов 2003].

Русское православие заимствовало у Греческой церкви и сохранило до сегодняшнего дня почти все жанры церковной литературы - в том числе агиографической - как прозаические, так и гимнические. Особой популярностью у верующих России всегда пользовались жития святых, а с конца XVIII в. - акафисты [Давыдов 2003].

Жизнь и подвиг святого описывались в Житиях - описаниях жизни и деяний святых, подвижников и т.п. Н.И. Толстой подчеркивает, что «одним из самых чтимых и популярных в старорусской книжности жанров являлись жития святых, образующие ядро средневековой литературы и имевшие важное значение для формирования христианского мировоззрения, занимая в иерархии древних славянских жанров ключевое место - на стыке конфессионально-литургической и национальной литератур» [Толстой 1988, 168].

Чудеса, которые описаны в житиях, совершены по молитвенному обращению к Богу и по воле самого Бога, без слышимого обращения. Они бывают: визуальные - Божественный Свет, аудиальные - Божественный Голос, тактильные - Божественная Сила.

В исследованиях житийной топики отмечается, что христианский чудотворец не совершает чуда сам, от своего имени, через него реализуется свободный дар Бога. Именно поэтому при описании чудес агиографическая традиция ориентирует автора жития на уподобление евангельской истории [Растягаев 2009, 35]. Читатель жития «одновременно и созерцает это видение, и приобщается к нему своей эмоциональной вовлеченностью» [Берман 1982, 160]. В самом простом схема- 
тическом виде эта эмоциональная вовлеченность воникает так: «В процессе создания сообщения на базе эмоции автора (эмоции 1) возникает экспрессия автора (экспрессия 1), т.е. автор превращает душевные переживания в выражение, при помощи которого эмоционально воздействует на реципиента. В процессе декодирования реципиент дешифрует, раскрывает экспрессию автора (экспрессию 1) превращает ее в свою экспрессию (экспрессию 2) и на основании ее создает свою собственную (эмоцию 2), скажем, начинает восхищаться, радоваться, грустить и т.п.» [Тошович 2006, 17].

Под топосом мы понимаем: [гр. topos - место, околица] - ритор., лит., перен. общее место, элементарный тематико-стилистический образец, литературный шаблон, риторическая схема, общепринятое суждение, устойчивая языковая фигура, речевая формула².

Наблюдения над текстами житий позволили К. Бондарь выделить 7 топосов, характерных для агиографического описания чуда: 1) вводимая рассказчиком экспозиция...; 2) место действия и обозначение ситуации..; 3) кризис..; 4) необязательный элемент: святой увещевает, отсылая к общеизвестному прецеденту, как правило, из Библии...; 5) молитва, состоящая из: а) прославления Бога...; б) самоуничижения и упования...; в) конкретной просьбы, иногда сопровождающейся апелляцией к библейскому прецеденту... Стандартное содержание молитвы иногда представлено без вводных мотивов...; 6) внезапное изменение, собственно чудо; 7) действие «чуда» [Бондарь 2001].

«Память преподобного отиа нашего Александра Свирского», 30 августа из Четий Миней святого Димитрия Ростовского (17 - нач. 18 века) ${ }^{3}$. Четьи Минеи вначале 20 века были переведены со старославянского на русский язык и дополнены ${ }^{4}$.

Построение текста данного жития соответствует каноническому житию византийского типа, в нем последовательно описывается жизнь святого - от рождения до смерти. Это житие-биос (описывается вся жизнь подвижника). По классификации В.В. Кускова, основанием ко-

2 Комлев Н.Г, 2006, Словарь иностранных слов, Тверь. [online] http://dic.academic. ru/dic.nsf/ [20.12.2013] [СИС].

3 Житія святыхъ на русском языке, изложенные по руководству Четих Миней святителя Димитрия Ростовского, Месяц август, Москва 1902, переизд. Москва 1997, (орфография изменена на современную автором статьи).

4 В более раннем издании Святой Димитрий Ростовский «Жития святых», (книга четвертая, июнь, июль, август Изд. Киево-Печерская Лавра 1764 г.) этого жития в день 30 августа нет, только пометка: «В тот же день Память преподобного Александра Свирского». 
торой является тип подвижника, главного героя жития, - эти жития можно отнести к типу "преподобнических" житий об основателях монастырей, простых иноках, посвятивших жизнь служению Богу и воспитывавших на своем примере монастырскую братию [Кусков 2003].

В топосах, представляющих жизнь преподобного с рождения до смерти, агиограф показывает трансформацию образа святого: в начале жития святой - объект Чуда, далее - соучастник Чуда и в конце жития сам Чудотвореи.

«Память преподобного отиа нашего Александра Свирского»-это текст, объемом свыше 1370 слов. Святость описываемого объекта соотносится с интенсивностью употребления слов, относящихся к общехристианской лексике: Бог, Господь, слова Господа, Иисус Христос, Cпас, Cпаситель, усмотрение Божие, милости Божией, Божественнье Писания (2), Божественные книги, Божественная Сила, Божественный свет, изволение Божие, монастьрь Пресвятой Богородииьл, Пречистая Его Мать, монастьрь святого Спаса, Боголепного Его Преображения, иерковь во имя Святой Троищьи, иерковь во имя Пресвятой Живоначальной Троииьл. В Тропаре и Кондаке, которые включает в Житие св. Димитрий Ростовский: единаго Христа, Моли Христа Бога, Христовым стопам последовати.

Агиограф использовал в Памяти ритмические конструкции. А как пишет Волков в пособии по риторике для духовных учебных заведений: «грамотный оратор знает, что размеренная, ритмичная речь - лучший способ расположить к себе собеседника» Волков 2001]. Агиограф создает ритм определенным чередованием слов с корнем - cвят-: Cвятой, Пресвятая, описывая жизнь преподобного от рождения до смерти. Тем самым он отмечает важные жизненные вехи:

(1) родился во владениях Великого Новгорода, в Обонежской области, которая была расположена по реке Ояти, в селе, называвшемся Мандера и находившемся против Островского монастыря Пресвятой Богородииь, честного Ее Введения;

(2) бил освящен святылм крешением;

(3) ...nришел в монастьрь святого Спаса, Боголепного Его Преображения;

(4) он построил иерковь во имя Святой Троиць и освятил ее;

(5) построил каменную иерковь во имя Пресвятой Живоначальной Tроuиь;;

(6) Оно подает многие исиеления приходящим с верою к святому гробу преподобного 
(7) в кондаке: Яко многосветлая звезда днесь в странах российских возсиял еси отче, вселився в пустьню Христовым стопам последовати усердно возжелел еси, и того святое иго на рамо твое взем честньий крест, умертвил еси труды подвиг твоих телесная взыграния.

Семь - символическое число в христианстве ${ }^{5}$, использование этого числа в житиях описывает и О.В. Гладкова [Гладкова 2012]. Посредством такого символического числа усиливается коммуникативное воздействие на слушателя.

В конце Памяти помещены Тропарь, глас 4, и Кондак, глас 8-й, преподобному Александру Свирскому. Они подолжают Песнь и становятся заключением, в котором резюмируется вся Песнь.

Непосредствено сам топос явления Святой Троицы святому Александру Свирскому состоит из 25 слов. Это немного, учитывая важность этого события.

Однажды он удостоился видеть Самого Бога, явившегося ему в трех Личах, и беседовать с Ним о том, как создать иерковь, построить монастырь и собрать братию.

Более короткого описания чуда, произошедшего со святым Александром Свирским, нет ни в одном из житий.

Как видим, агиограф это событие представил преимущественно с помощью инфинитива. Н.А. Стародубцева, изучавшая инфинитив в старорусских житиях, пишет о присущей инфинитиву полифункциональности, обусловливающей расширение и обогащение его функционально-семантических свойств в житийных текстах, что позволяет данной языковой единице выступать одним из важных средств выражения житийного содержания [Стародубцева 2008]. И там же: «Как средство выражения топосов, раскрывающих типы святости преподобничество, святительство, мученичество, святые жены, инфинитив употребляется с модальными значениями возможности, желательности, долженствования и необходимости» [Стародубцева 2008]. Именно это наблюдается в описании ситуации чуда, произошедшего со святым Александром Свирским.

\footnotetext{
5 Седьмой день недели священный - воскресенье, Семь смертных грехов, Семь мучеников эфесских, Семь таинств церкви, Во время соборования за больного молятся 7 священников, семь свечей в светильнике алтарном и семь - в запрестольном, Семь Вселенских соборов, признаваемых православием, 7 постоянных членов Священного синода РПЦ, над православными храмами часто семь куполов. [online] http://www. znamenye.ru/index.php?name $=$ news\&op=new\&s_id $=257$ [15.12.2013].
} 
Глаголы совершенного вида, обозначая действия, ограниченные определенным пределом, сосредоточивают внимание читателя не только на процессе (а нередко и не столько на процессе), но и на том или ином его моменте, стадии его развития, они представляют действие как конкретный факт. Они используются для выражения единичных действий в определенный момент, для рассказа о событиях, сменяющих одно другое, об изменении в какой-либо ситуации. Картина, описываемая глаголами совершенного вида, конкретна, динамична, такие глаголы движут развитие сюжета [Рахманова, Суздальцева 1997].

По поводу этого описания мы уже отмечали, что все чудесные события здесь выражены двумя последовательностями инфинитивов: «первые два, распространяющие глагол удостоился: видеть и беседовать. А далее - указывающие на предмет беседы: создать - nостроить собрать. Отсутствуют начальное и конечное описания, Дмитрий Ростовский сохранил только способ явления Бога Преподобному. В одном предложении инфинитивы, которые называют действие без указания на время, на отношение к действительности и к лицу - субъекту действия, обозначают процесс как таковой, и поэтому не могут передать ни проблему узнавания Бога, ни динамику трансформации Его образа. В предельно лаконичном описании нет и сколько-нибудь явного указания на чудесность происходящего. Для агиографа, возможно, важно было максимально сжатое описание события, имеющее конструкцию, удобную для устного восприятия» [Anchimiuk O., Zaika V., 2014].

Святой Димитрий Ростовский отразил одним глаголом то, что агиографы других житий святого передали развернутым диалогом, он заменил диалог описанием, которое в нарратологии называется «резюме» ${ }^{6}$ или «реферативным эпизодом» ${ }^{7}$, и этот прием «неговорения», как нам кажется, подчеркивает смирение и покорность святого.

Наказ Бога святому Александру Свирскому описывается глаголами созидательной деятельности, обозначающими 'прочессы создания объекта в результате физического труда' и употребленными в прямом значении: создать, построить, собрать. Так как инфинитив, как известно, называет действие или процессуальное состояние без указания на время действия, его отношение к действительности и к субъекту действия, можно предположить, что для агиографа важен был именно процесс.

\footnotetext{
6 Термин Ж. Женетта.

7 Термин В.И. Заики.
} 
Инфинитивом с существительным: видеть Самого Бога - собрать братию - агиограф создает причинно-следственные связи, видеть, чтобы собрать; он показывает распространение учения Христа святым Александом Свирским.

В самом начале повествования агиограф использует эпитет блаженный ${ }^{8}$ по отношению к Александру. В слове блаженный агиограф выделяет этический аспект. Рассказывая о детстве и юности, называет св Александра Свирского блаженный отрок, боголюбивый юноша, дивный отрок. Родители же обращаются к святому сын мой.

\section{- Акафист}

Акафист - христианское хвалебное церковное песнопение. Исполняется стоя всеми присутствующими [БЭС].

Необычайно плодовитым акафистографом оказался духовный писатель А. Ф. Ковалевский ${ }^{9}$ - его перу принадлежит внушительная часть русского акафистографического материала, в том числе и Акафист святому преп. Александру Свирскому (1875).

Позднейший акафист в своем классическом варианте, - это, par excellence, торжественное песнопение, эпидейктический гимн в честь Иисуса Христа, Богоматери, ее чудотворных икон, святых, в память праздничных событий библейской и церковной истории и проч. [Давыдов 2003]. Акафист обладает жесткой многоуровневой структурой. Песнопение состоит из 25 песенных строф: 13 кондаков и 12 икосов, чередующихся в шахматном порядке. Это крупнейшие структурные единицы акафиста. [Людоговский 2007].

В текстах Акафистов традиционно присутствует как историческое, так и догматическое содержание: кондаки (меньшие по объему) задают тему, а икосы (большие по объему) - ее развивают. Икосы имеют более сложное, чем кондаки, строение, в них выделют три части: 1) повествовательную; 2) блок хайретизмов - воззваний к святому (или Богу, Богородице, ангелам), это обычно наболее пространная часть икоса; 3) рефрен - повторяющийся во всех икосах, а также в первом кондаке хайретизм.

\footnotetext{
8 «"Блаженными" по преимуществу называется особый разрядъ св. подвижниковъ и подвижницъ, иначе называемых юродивыми. Этот видъ подвижничества состоитъ в томъ, что принявшій или принявшая на себя этотъ подвигъ ради Христа и спасенія своей души отказывается оть общеприятого образа жизни, дњлается добровольным

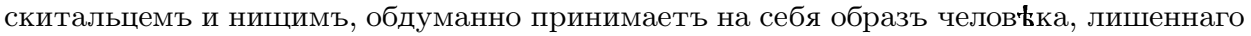
здраваго ума...» [ППБЭ].

9 О нем см. подр.: Милорадович Г., 1902, Составитель акафистов Андрей Федорович Ковалевский (1840-1901), [w:] Русский Архив, Москва, № 4.
} 
Рассмотрим Акафист святому преподобному Александру, игумену Свирскому, чудотворцу. Акафист состоит из 2713 слов. Рассматриваемый топос соответствует Икосу 7 и занимает 126 слов.

Он состоит из повествования, из которого слушатель, незнакомый с житием святого, узнает о событиях его жизни:

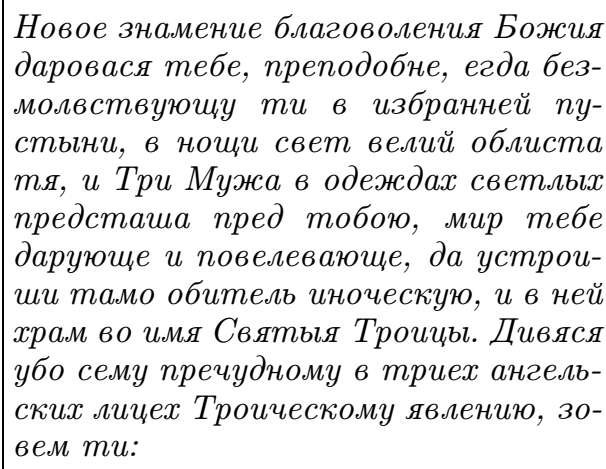
даровася тебе, преподобне, егда безмолвствуюшу ти в избранней пустыни, в нощи свет велий облиста тя, и Три Мужа в одеждах светльх предсташа пред тобою, мир тебе дарующе и повелевающе, да устроиши тамо обитель иноческую, и в ней храм во имя Святыля Троицьи. Дивяся убо сему пречудному в триех ангельских личех Троическому явлению, зовем ти:

Новое знамение благоволения Божия даровалось тебе, преподобный, когда безмолвствуюший ты в избранной пустыне, ночью великий свет тебя осветил, и Три мужа в светльх одеждах предстали пред тобой, мир тебе даруюшие и повелевающие (повелели) тебе устроить там обитель иноческую(монастьрь) и в ней храм во имя Святой Троиць. Удивляясь этому чудесному в трех ангельских лицах Явлению Святой Троицьи, взьваем, приветствуем (обрашаемся) $\kappa$ тебе:

Подробности чудесного явления следующие: автор Акафиста указывает время: в нощи, состояние безмолвно молящегося монаха, а также дает описание Святой Троицы, Три Мужа в одеждах светльх предсташа пред тобою. Подробности эти присутствуют и в одном из первых житий святого, написанном игуменом Иродионом.

Существенным отличием топоса в акафисте является также обрамление события чуда. Акафист начинается содержательным элементом, отсутствующим в житии. Это предваряющее события чуда обобщение: Новое знамение благоволения Божия даровася тебе, а заканчивается обращением к святому: зовем ти.

«Личными в старославянском языке были местоимения 1-го лица (обозначение самого говорящего, автора) и 2-го (обозначение собеседника); для указания на 3 -е лицо или предмет использовались указательные местоимения» [Хабургаев 1974, 208]. В Акафисте повествование ведется во 2 лице, поэтому обращение к святому как к собеседнику в диалоге. По мнению Г.А. Хабургаева, личные местоимения в функции подлежащего употреблялись в тех случаях, «когда говорящему (автору) было необходимо особо подчеркнуть действующее лицо, т.е. тогда, когда местоимение наделялось определенной смысловой нагрузкой» [Хабургаев 1974, 396]. 
Следующие части Акафиста интересны своей композицией и особенностями порядка слов:

(1) Радуйся, в смертнем телеси безсмертия зарею просвещеннblü.

(2) Радуйся, таинниче ${ }^{10}$ Пресвятыля и Единосущнья Троищь.

(3) Радуйся, самовидче 11 неизреченнаго Божия явления.

(4) Радуйся, собеседниче светоносньх Ангельских Сил.

(5) Радуйся, созерцателю лучезарнаго Божественнаго видения.

(6) Радуйся, причастниче ${ }^{12}$ огнезрачнаго ${ }^{13}$ трисолнечнаго сияния.

(7) Радуйся, поклонниче Триипостаснаго Божества.

Семь хайретизмов, ритмизированы не только анафорическим повтором Радуйся, но и последовательностью во 2-7 строках вокативов таинниче, самовидче, собеседниче, созериателю, поклонниче, которые характеризуют святого как свидетеля чуда. Обращает на себя внимание что все вокативы, в том числе и хиастически расположенное причастие в первой строке просвещенный, имеют семантику действия, повторяя и детализируюя процесс чудесного явления. Интересно, что составитель Акафиста, вероятно, не ставил целью сделать последовательность вокативов соответствующим последовательности событий чуда.

Рефрен - третий элемент Акафиста - имеет сходное начало: анафорическое радуйся:

1. Радуйся, в смертнем телеси безсмертия зарею просвещеннblü.

2. Радуйся, на земли небеснаго посещения удостоенный.

3. Радуйся, смирением высокая стяжавьй.

4. Радуйся, нищетою богатую милость Господню улучивый ${ }^{14}$.

5. Радуйся, сеявьй слезами радость присносушную.

6. Радуйся, приемый исполнение обетований непреложных $x^{15}$.

7. Радуйся, преподобне Александре, Свирский чудотворче.

Однако мы видим, что расположение вокативов в рефрене иное, чем в предыдущем фрагменте. Первые четыре строки содержат во-

\footnotetext{
10 Таинниче - тайновидец, тот которому открыты тайны

11 Самовидче - очевидный свидетель

12 Причастниче - участник

13 Огнезрачный - огнеобразный

14 Улучил - получил, достиг

15 Принявший исполнение обещаний нерушимых
} 
кативы в конце строки, чем задают иную ритмическую норму, нарушение которой в строках 5 и 6 подготавливает восприятие последней строки рефрена. Особенности строки в том, что основной признак святого стоит в сильной позиции и является не вокативом, а основным эпитетом с сематикой чуда.

Память и Акафист, содержащие топос «явление Святой Троицы святому Александру Свирскому», читаются в церкви и воспринимаемы на слух. Однако каждый жанр своими средствами реализует этот топос. В памяти событие чуда передается прозаически, скупо, как бывшее «на самом деле», оно обращает переживающего церковную службу прихожанина к временам истории. В Акафисте же топос реализован по-иному: событие чуда передано с точки зрения «здесь и сейчас», с точки зрения верующего, который прославляет святого за его подвиг, чему способствует значительная риторическая интенсивность текста.

\section{Условные сокращения}

БЭС - Большой энциклорпедический словарь 2000 [online] http://dic.academic.ru/dic.nsf/enc3p/49678 [20.12.2013]

ППБЭС - Полньй православный богословский энииклопедический словарь, т. 2, Санкт-Петербург 1912. [online] http://www.biblioteka3.ru/biblioteka/raznoe/pdf.html [20.12.2013]

СИС - Комлев Н.Г, 2006, Словарь иностранньх слов, Тверь. [online] http://dic.academic.ru/dic.nsf/ [20.12.2013]

\section{Литература}

Акафисты русским святьлм, 1995, Санкт-Петербург, [online], http://akafistnik. ru/akafisty-russkim-svyatym/

Anchimiuk O., Zaika V., 2014, Описание чуда явления Святой Троиць святому Александру Свирскому (на материале четьрех житийньх текстов), "Linguodidactica" XVIII, Białystok 2014, s. 7-21

Берман Б.И., 1982, Читатель жития (Агиографический канон русского средневековья и традииия его восприятия), [w:] Художественный язык средневековья, с. 159-183.

Бондарь К., 2001, Поэтика житийньх описаний «чуда» (по данньлм восточнославянских средневековьх текстов), [w:] Концепт чуда в славянской и еврейской культурной традиции, Москва, с. 45-51. 
Bouflet J., 2011, Historia cudów: od średniowiecza do dziś, Warszawa.

Волков А.А., 2001, Курс русской риторики, Москва, [online], http://www.krotov. info/library/03_v/ol/kov_01.html\#33 [10.09.2014].

Гладкова О.В., 2012, Житие Евстафия Плакиды как источник чтения о Борисе и Глебе Нестора: вопрось текстологии, поэтики и идеологии, "Древняя Русь", № 1, с. 28-38, [online], http://www.bogoslov.ru/biblio/ text/2787938/index.html.pdf [20.12.2013]

Давыдов И.П., 2003, Православный акафист русским святым (религиоведческий анализ), Канд. дис., Москва.

Житие преподобного и богоносного отца нашего Александра Свирского Чудотвориа, составленное учеником его игуменом Иродионом. Текст Жития публикуется по изданию: Житие и чудеса преподобного Александра Свирского, 1905, Санкт-Петербург.

Кусков В.В, 2003, История древнерусской литературы, Москва.

Людоговский Ф.Б., 2007, Хайретизмы в акафистах святым: стуктурно-количественная характеристика, "Православный собеседник", № 1 (14), [online], http://kds.eparhia.ru/publishing/sobesednik/fourteen/lydogovskiy/ [10.07.2014]

Святитель Димитрий, митрополит Ростовский Жития святьх (Четьи Минеи), [online], http://predanie.ru/lib/book/read/140855/\#toc864 [10.09. 2013]

Растягаев А.В., 2009, Житийная топика в прозе писателей XVIII столетия (Кантемир, Тредиаковский, Фонвизин), Самара.

Рахманова Л.И., Суздальцева В.Н., 1997, Современный русский язык Лексика Фразеология Морфология, Москва, [online], http://www.bibliotekar.ru/ russkiy-yazik-2/162.htm [20.12.2013]

Стародубцева Н.А., 2008, Развитие функиионально-семантических свойств инфинитива в старорусских житийньх текстах, Автореферат канд. дис., Волгоград.

Толстой Н.И., 1988, История и структура славянских литературных языков, Москва.

Тошович Б., 2006, Экспрессивный синтаксис глагола русского и сербского/хорватского язикков, Москва.

Федотов Г.П., 1931, Святые Древней Руси, Париж, [online], http://vehi.net/fedo tov/svyatye/00.html [10.09.2014]

Хабургаев Г.А., 1974, Старославянский языю, Москва. 


\section{TOPOS OF REVELATION OF THE TRINITY TO ST ALEXANDER SVIRSKY IN THE LIVE AND THE AKATHIST}

\section{S U M M A R Y}

The article deals with the problem of topos - a miracle of The Trinity revelation, which connects The Live and The Akathist dedicated to saint Alexander Svirsky. The hagiographical text is represented by Pamiat', which could be read in the saint's name day. In this text both hagiographical canons and figures of speech are presenting. The Akathist - it is a kind of Easter Orthodox liturgical poetry praising with magnificent a saint in given topos (Ikos 7).

Olga Anchimiuk e-mail: anchimiuk.olga@o2.pl 